\title{
Biological Effects of Osteoblast-Like Cells on Nanohydroxyapatite Particles at a Low Concentration Range
}

\author{
Xiaochen Liu, ${ }^{1}$ Jie Wei, ${ }^{1,2}$ and Shicheng Wei ${ }^{1,3}$ \\ ${ }^{1}$ Center for Biomedical Materials and Tissue Engineering, Academy for Advanced Interdisciplinary Studies, Peking University, \\ Beijing 100871, China \\ ${ }^{2}$ Key Laboratory for Ultrafine Materials of Ministry of Education, East China University of Science and Technology, \\ Shanghai 200237, China \\ ${ }^{3}$ Department of Oral and Maxillofacial Surgery, School of Stomatology, Peking University, Beijing 100081, China
}

Correspondence should be addressed to Jie Wei, nic750@263.net and Shicheng Wei, sc-wei@pku.edu.cn

Received 29 April 2011; Revised 19 July 2011; Accepted 19 July 2011

Academic Editor: Somchai Thongtem

Copyright (C) 2011 Xiaochen Liu et al. This is an open access article distributed under the Creative Commons Attribution License, which permits unrestricted use, distribution, and reproduction in any medium, provided the original work is properly cited.

\begin{abstract}
The biological effects of osteoblast-like MG-63 cells on nanohydroxyapatite (n-HA) at the low concentration range $(5-25 \mu \mathrm{g} / \mathrm{mL})$ for 5 days was investigated. The results showed the viability and actin cytoskeleton of the cells descended with the increase of the concentration of n-HA, and the actin cytoskeleton of cells was depolymerised and became more disordered. Apoptotic rate of cells $(1.85 \%, 1.99 \%$, and $2.29 \%)$ increased with the increase of $\mathrm{n}-\mathrm{HA}$ concentration $(5,15$, and $25 \mu \mathrm{g} / \mathrm{mL})$ and become significantly higher than the control. Total intracellular protein content decreased with n-HA concentration increase, showing significant difference between $25 \mu \mathrm{g} / \mathrm{mL}$ and the control, and no significant change of ALP activity was observed at the 5th day. The results revealed that the cell growth was inhibited by n-HA in a concentration-dependent manner, and the obvious biological effects of MG-63 cells on n-HA existed at the low concentration range from 5 to $25 \mu \mathrm{g} / \mathrm{mL}$.
\end{abstract}

\section{Introduction}

Hydroxyapatite (HA), with the structural formula of $\mathrm{Ca}_{10}\left(\mathrm{PO}_{4}\right)_{6}(\mathrm{OH})_{2}$, is the principal inorganic constituent of human bone [1]. Due to its good biocompatibility and osteoconductivity [2], the HA biomaterials have been widely used in clinic, for example, as artificial bone, coatings on titanium prostheses surface [3-5]. However, HA particles or wear debris from HA coating can cause inflammatory reaction, especially for the nanosize particles $[6,7]$. Therefore, it is imperative to be assessed, they are even used in clinic with a very small amount or a relatively low concentration at the local region.

In recent years, it was reported that nanohydroxyapatite (n-HA) could inhibit the growth of osteoblasts in a concentration-dependent manner. Xu et al. had shown that the apoptotic and inhibition ratios of osteoblasts were rising with the increase of the concentration $(20,40,60$, $80,100 \mu \mathrm{g} / \mathrm{mL}$ ) of the n-HA with the size of $10-20 \mathrm{~nm}$ [8]. The similar results were reported in Fu et al. work (cell responses to n-HA with the concentration of $50.8 \mathrm{mg} / \mathrm{mL}$ ) and Motskin et al. (n-HA concentrations ranges from 31 to $500 \mathrm{mg} / \mathrm{mL}$, and $\mathrm{n}-\mathrm{HA}$ was toxic at higher concentrations of more than $250 \mathrm{mg} / \mathrm{mL}$ ) $[9,10]$. Furthermore, Liu et al. studied the effects of n-HA (concentrations of 50, 75, 100, 150 , and $200 \mathrm{mg} / \mathrm{L}$ ) on proliferation and apoptosis of human hepatoma BEL-7402 cells [11]. The concentration of nHA was relatively high from 20 to $200 \mu \mathrm{g} / \mathrm{mL}$ in these works mentioned above. However, HA or n-HA coating implants had been proven to produce small amounts of particulate debris $\left(52 \pm 51\right.$ particles per $\left.\mathrm{mm}^{2}\right)$ in acetabular components from patients with osteolysis [12], in which the concentration is apparently lower than that mentioned above. Additionally, osteoblasts are selected since these cells stay in direct contact with the implanted materials during the bone growth stage. If osteoblasts die on the implanted materials surface because of the presence of debris, the new bone will not be generated. Thus, the aim of this study was to investigate the responses of MG-63 cells cultured with n-HA slurry at a relatively low concentration range and to evaluate 
the influence of n-HA particles with low concentration on the cell morphology, proliferation, and differentiation.

\section{Materials and Methods}

2.1. Preparation of $n-H A$. n-HA particle was synthesized at room temperature and prepared by slow-mixing calcium nitrate and ammonium phosphate solutions at $\mathrm{pH} 10.0$ and $90^{\circ} \mathrm{C}$ under stirring [13]. The precipitated crystals were aged in mother liquor for 2 days. Next, they were washed three times with distilled water and dried at room temperature. The morphology of the n-HA was observed by transmission electron microscopy (TEM, Tecnai F30, FEI Company) with an accelerating voltage of $200 \mathrm{keV}$. n-HA was sterilized by ultraviolet before in vitro experiments. Stock solution was made at the concentration of $50 \mu \mathrm{g} / \mathrm{mL}$ with MEM (Minimum Essential Medium, Gibco, Grand Island, NY). After ultrasonic dispersion for $15 \mathrm{~min}$, stock solution was added to the MG-63 cells at final concentration of 5,10 , 15,20 , and $25 \mu \mathrm{g} / \mathrm{mL}$.

2.2. Cell Culture and Morphology. Human osteoblast-like MG-63 cell line (American Type Culture Collection, Va, USA) was used in this study. Cells were seeded at a density of $2 \times 10^{4}$ per well in 48 -well plates. Incubation was performed in MEM containing 10\% fetal bovine serum (FBS, Gibco), $100 \mu \mathrm{g} / \mathrm{mL}$ streptomycin and $100 \mathrm{U} / \mathrm{mL}$ of penicillin in a humidified atmosphere with $5 \% \mathrm{CO}_{2}$ at $37^{\circ} \mathrm{C}$. At the 5 th day, cells were examined by inverted phase contrast microscope (Nikon Eclipse TS100, Japan) to determine whether the cell morphology was influenced by n-HA concentration or not.

2.3. Immunofluorescence and Cytoskeletal Observation. MG63 cells were cultured on cover slips at $37^{\circ} \mathrm{C}$ in $5 \% \mathrm{CO}_{2}$ humidified atmosphere. After 5 days of culture, cells were washed with PBS and fixed with $3 \%(\mathrm{w} / \mathrm{v})$ paraformaldehyde in PBS buffer for $20 \mathrm{~min}$ at room temperature. The samples were then washed with PBS and permeabilized with $0.1 \%$ Triton X-100 at $4^{\circ} \mathrm{C}$ for $5 \mathrm{~min}$, before incubated with $1 \%$ bovine serum albumin/PBS at $37^{\circ} \mathrm{C}$ for $5 \mathrm{~min}$ to block the nonspecific binding. This was followed by adding fluorescein isothiocyanate- (FITC-) conjugated phalloidin (Sigma) at $37^{\circ} \mathrm{C}$ to stain the DNA of the MG-63 cells for $20 \mathrm{~min}$. They were then rinsed and incubated for $10 \mathrm{~min}$ at room temperature with DAPI. Samples were mounted in Vectorshield fluorescent mountant (Vector Laboratories, UK) and observed by a Leica SP2 laser scanning confocal microscope.

2.4. MTT Assay. MG-63 cells were seeded at a density of $0.5 \times 10^{4}$ per well in 96-well plates. At 6 hours after seeding, cells were rinsed with phosphate-buffered saline (PBS) and added $200 \mu \mathrm{L}$ of the different particle dilutions to the cells or $200 \mu \mathrm{L}$ medium (as the control). After 5 days, the cell viability was evaluated using the MTT (3-(4,5-dimethyl-2-thyazolyl)-2,5-diphenyl-2Htetrazolium-bromide, Germany) assay after washing three times with PBS. Cells were incubated at $37^{\circ} \mathrm{C}$ for 4 hours after the addition of $100 \mu \mathrm{L}$ fresh medium and $10 \mu \mathrm{L}$ of MTT $(5 \mathrm{mg} / \mathrm{mL})$ to each well. After solubilization of the blue formazan product with dimethylsulfoxide, $100 \mu \mathrm{L}$ of dye solution from each well was transferred to 96-well plates. Absorbance was measured at $570 \mathrm{~nm}$ using a microplate reader (Bio-RAD Model 680) and cell viability was expressed as percentage of the control.

2.5. Flow Cytometric Analysis. MG-63 cells were centrifuged and stained according to the manufacturer's specifications for analysis by flow cytometry. Propidium iodide (PI, $50 \mu \mathrm{g} / \mathrm{mL}$ ) staining was performed for $20 \mathrm{~min}$ at room temperature. All data were obtained by a FACSCalibur (BD Biosciences) flow cytometer at least 10,000 events recorded for each condition, and the percentage of the apoptotic cells were analyzed using Summit software 5.0. Histograms of DNA content ( $x$-axis, PI-fluorescence) versus counts ( $y$-axis) were displayed.

2.6. Total Intracellular Protein Content. This procedure was performed according to BCA Protein Assay Reagent Kit (Sigma) [14]. Total protein content in the cell lysate was determined at $570 \mathrm{~nm}$ using a microplate reader (BioRAD Model 680). Total intracellular protein (expressed as $\mu \mathrm{g} / \mathrm{mL}$ ) produced by osteoblasts cultured with different concentrations of n-HA was determined by a standard curve of absorbance versus known concentration of albumin run in parallel with experimental samples. Total intracellular protein produced by MG-63 cells cultured without n-HA was used as a control.

2.7. Alkaline Phosphatase Activity. The osteoblastic phenotype of the cells was determined by alkaline phosphatase (ALP) activity and by the formation of mineral deposits in the extracellular matrix. Briefly, the cells after cocultured for 5 days were washed with PBS and then lysed in $0.5 \mathrm{~mL}$ PBS containing $0.1 \mathrm{M}$ glycine, $1 \mathrm{mM} \mathrm{MgCl}$, and $0.05 \%$ Triton X100. The lysate solution was incubated with p-nitrophenyl phosphate (pNPP) solution at $37^{\circ} \mathrm{C}$ for $30 \mathrm{~min}$. The light absorbance of these samples was measured on a Microplate Reader (Model 680) at $405 \mathrm{~nm}$. ALP activity of MG-63 cells cultured without n-HA served as a control.

2.8. Statistical Analysis. All quantitative tests were carried out in quadruplicate, and the mean values with standard deviations were calculated. Statistical analysis of data was accomplished by $t$-test using software SPSS11.0 for Windows.

\section{Results}

3.1. XRD and TEM Analysis. The XRD pattern of synthesized n-HA particles are presented in Figure 1(b), which exhibited five main diffraction peaks located at $2 \theta=26^{\circ}, 32^{\circ}, 40^{\circ}$, $47^{\circ}$, and $50^{\circ}$, respectively. Compared with the standard XRD pattern of HA in the PDF card, the XRD pattern of synthetic n-HA revealed the presence of all expected major HA peaks. 


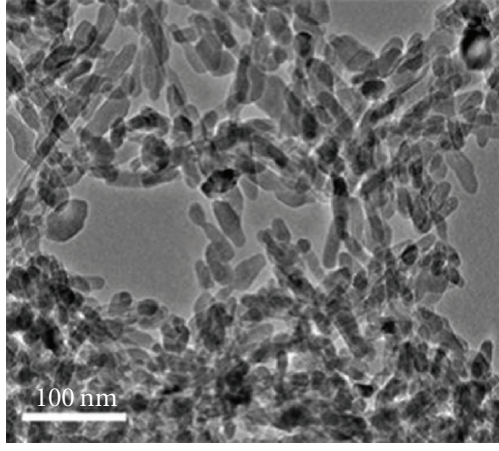

(a)

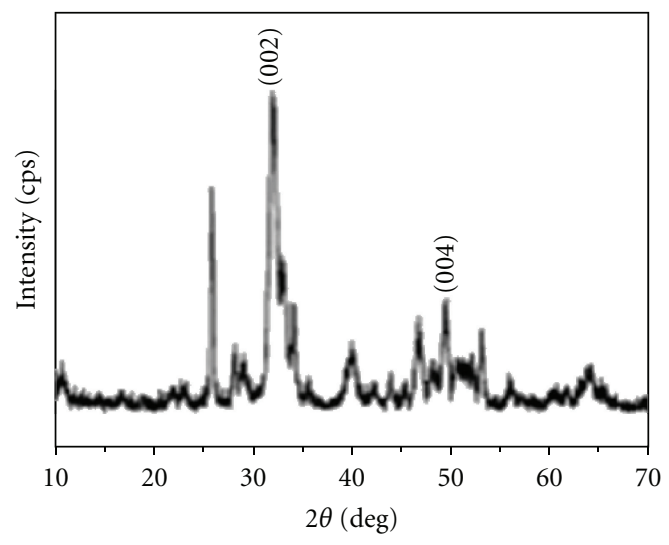

(b)

FIgURE 1: TEM image (a) and XRD pattern (b) of n-HA particles.

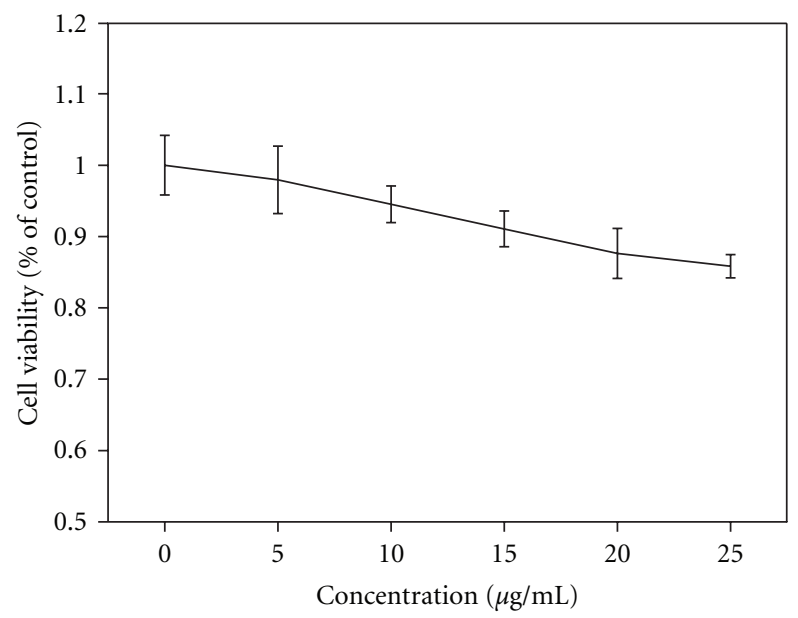

Figure 2: Viability of osteoblast cells responding to different concentrations n-HA solution for 5 days. Values are the mean \pm $\mathrm{SD}$ (six parallel samples for each concentration).

TEM observation showed that $\mathrm{n}$-HA particles possessed short rod-like shape with size $10-20 \mathrm{~nm}$ in diameter and $40-60 \mathrm{~nm}$ in length $(n=100)$ in (Figure $1(\mathrm{a}))$. This size was measured with ruler according to the scale in the SEM pictures.

3.2. Cell Viability Assays. MTT (3-(4,5-Dimethylthiazol-2yl)-2,5-diphenyltetrazolium bromide) colorimetric analysis was used to measure the viability of cells, which interacted with different concentrations of n-HA. The cell viability was expressed as percentage over the untreated control. As shown in Figure 2, osteoblasts viability decreased with the increase of n-HA concentration at 5 days. The results indicated that cell growth and proliferation up to 5 days was inhibited by $\mathrm{n}$-HA slurry in the range of 5 to $25 \mu \mathrm{g} / \mathrm{mL}$.

3.3. Cell Morphology Observation. After culturing for 5 days, cells spread well with different n-HA concentration, as shown in (Figures 3(b), 3(c) and 3(d)). In the control group, cells exhibited a spindle and stellate morphology with whole cellular membrane and rich cellular plasma, as shown in Figure 3(a). Due to the high cell density, it is hard to present the differences between the experimental groups and the control.

3.4. Immunofluorescence and Cytoskeletal Observation. The development of the cell cytoskeleton was studied by immunofluorescent staining of actin cytoskeletal proteins in order to assess the quality of cellular adhesion. Immunofluorescence images of MG-63 cells grown with the control groups showed a network of well-formed stress fibres of normal filamentous morphology (Figure 4(a)). For the experimental groups, the actin cytoskeleton was partially depolymerised, exhibiting incomplete stress fibres, which might relate with the nHA concentration and (Figures 4(b), 4(c) and 4(d)). Those results showed that the cell adhesion was affected by the nHA concentration, particularly at the high concentration.

3.5. Cell Apoptosis Analysis. A flow cytometry assay was performed to evaluate the apoptosis rate of MG-63 cells with different n-HA concentrations. It could be seen that the percentage of apoptotic cells increased with increase n-HA concentration (Figure 5 ). The average apoptosis rate for $0 \mu \mathrm{g} / \mathrm{mL}, 5 \mu \mathrm{g} / \mathrm{mL}, 15 \mu \mathrm{g} / \mathrm{mL}$, and $25 \mu \mathrm{g} / \mathrm{mL}$ group was $1.66 \pm 0.05 \%, 1.85 \pm 0.06 \%, 1.99 \pm 0.11 \%$, and $2.29 \pm$ $0.09 \%$, respectively. Significant difference between n-HAtreated groups and untreated control in apoptotic rates $(P<$ 0.01 ) was noted.

3.6. Total Protein Content Analysis. After culturing for 5 days, the total protein content of each group was detected. The value for the $20 \mu \mathrm{g} / \mathrm{mL}$ or $25 \mu \mathrm{g} / \mathrm{mL}$ experimental groups were significantly higher $(P<0.05)$ than the control group $(0 \mu \mathrm{g} / \mathrm{mL})$ (as shown in Figure 6).

3.7. Alkaline Phosphatase Activity Assay. Cell differentiation was assessed by measuring the ALP activity of MG-63 cells cultured with different concentrations of n-HA for 5 days. As 


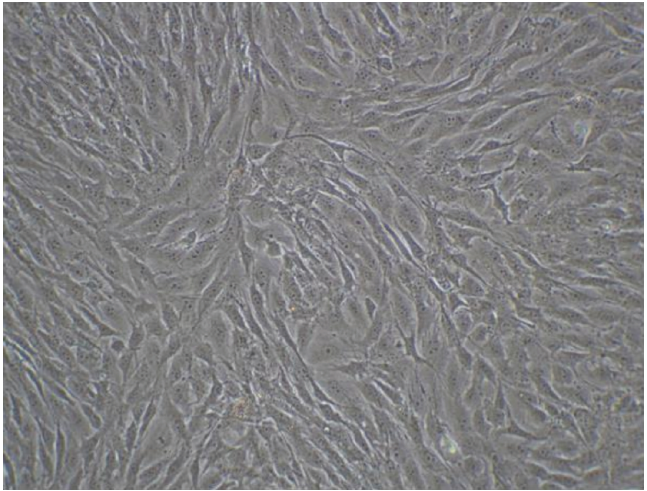

(a)

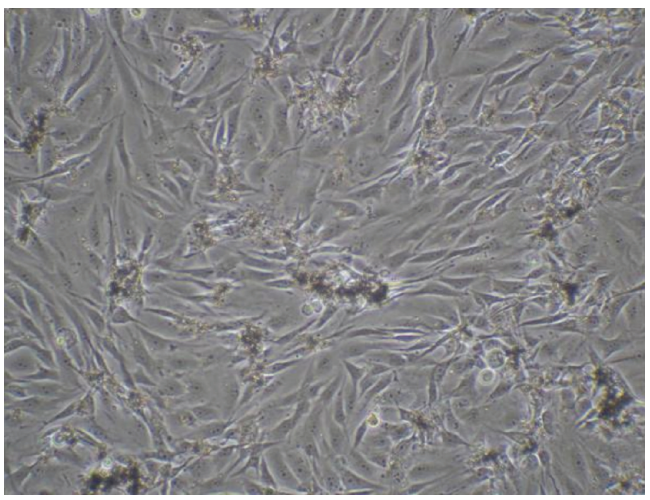

(c)

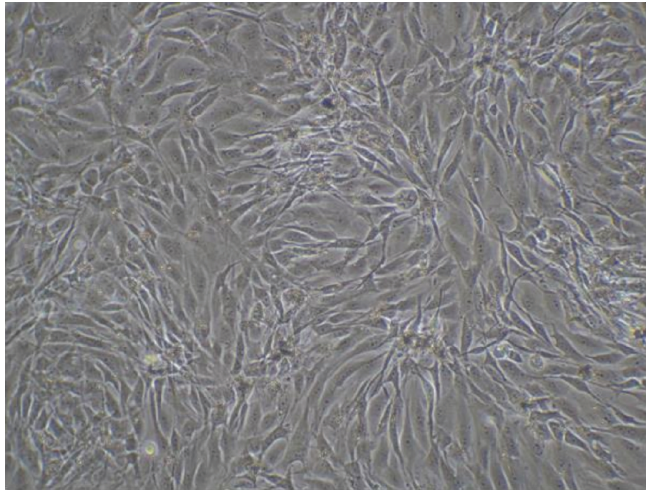

(b)

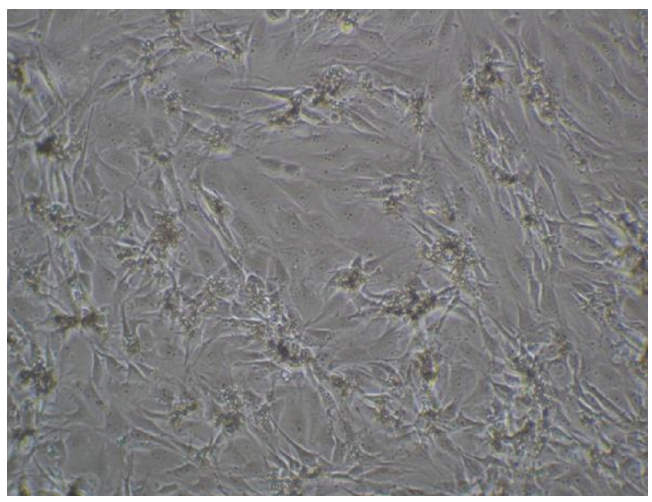

(d)

Figure 3: Microscopic photographs of MG-63 cells cultured with (a) $0 \mu \mathrm{g} / \mathrm{mL}$, (b) $5 \mu \mathrm{g} / \mathrm{mL}$, (c) $15 \mu \mathrm{g} / \mathrm{mL}$, (d) $25 \mu \mathrm{g} / \mathrm{mL}$ n-HA for 5 days; Magnification 100x.

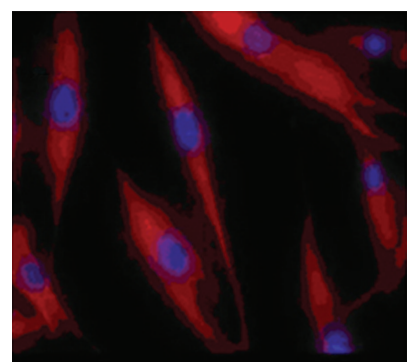

(a)

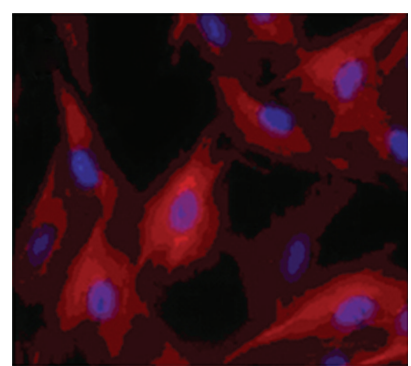

(b)

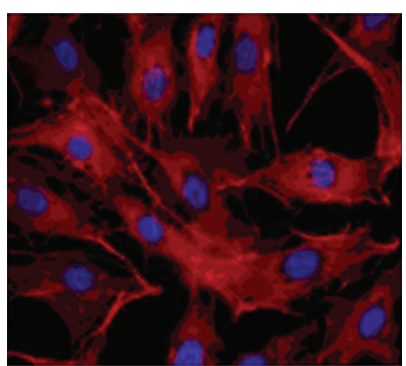

(c)

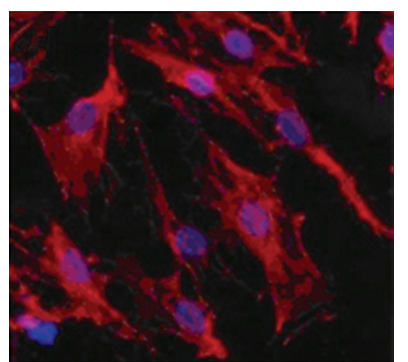

(d)

FIgURE 4: Actin cytoskeletal organization (red, labelled with phalloidin-FITC, counterstained with DAPI for nuclei in blue) of MG-63 cells cultured with (a) $0 \mu \mathrm{g} / \mathrm{mL}$, (b) $5 \mu \mathrm{g} / \mathrm{mL}$, (c) $15 \mu \mathrm{g} / \mathrm{mL}$,(d) $25 \mu \mathrm{g} / \mathrm{mL} \mathrm{n}-\mathrm{HA}$ for 5 days (Magnification 200x). The less-organized actin stress fibers were observed with the increase of n-HA concentration.

shown in Figure 7, no statistical difference was observed for the ALP activities of cells among the different groups.

\section{Discussions}

To date, many studies have, focused on the size, shape, and sintering temperature of nanohydroxyapatite (n-HA). However, little effort has been put in investigating the effects of concentration of n-HA on the cell responses, especially for the relatively low concentration. In this study, the n-HA with the size of around $10-20 \mathrm{~nm}$ in diameter and
$40-60 \mathrm{~nm}$ in length was prepared under normal pressure and temperature, different from other methods reported under a certain pressure [15]. The specifically biological effects of $\mathrm{n}$-HA on cells were mainly dependent on its concentration $[8,11]$. Therefore, the biological effects of MG-63 cells on n$\mathrm{HA}$ at a relatively low concentration range $(5-25 \mu \mathrm{g} / \mathrm{mL})$ was investigated for 5 days in this study.

Our study suggested that $\mathrm{n}-\mathrm{HA}$ in the concentration range from 5 to $25 \mu \mathrm{g} / \mathrm{mL}$ could inhibit osteoblastic viability and the proliferation rate decreased lineally with the increase of n-HA concentration. This agreed with the study of 


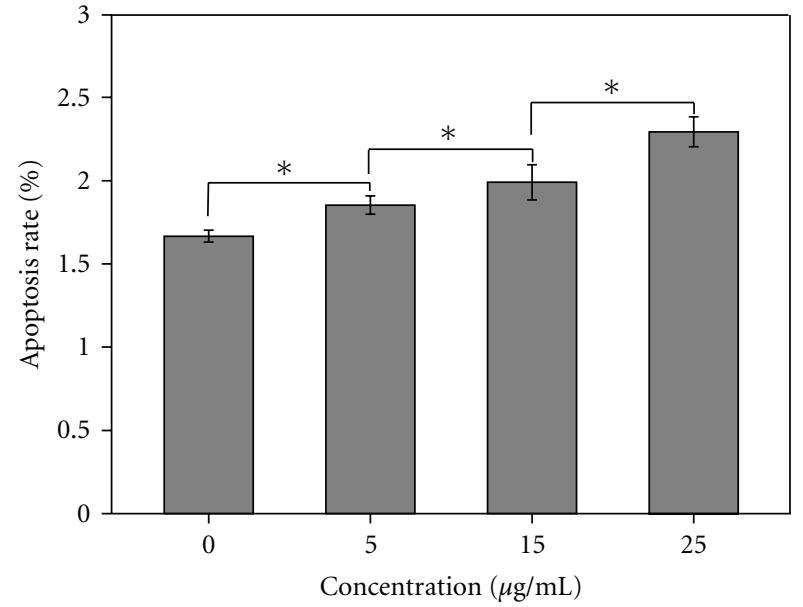

FIGURE 5: Flow cytometric analysis of MG-63 cells apoptosis with different concentrations of $\mathrm{n}-\mathrm{HA}$ for 5 days. Values are the mean \pm SD (six parallel samples for each concentration) ${ }^{*} P<0.01$.

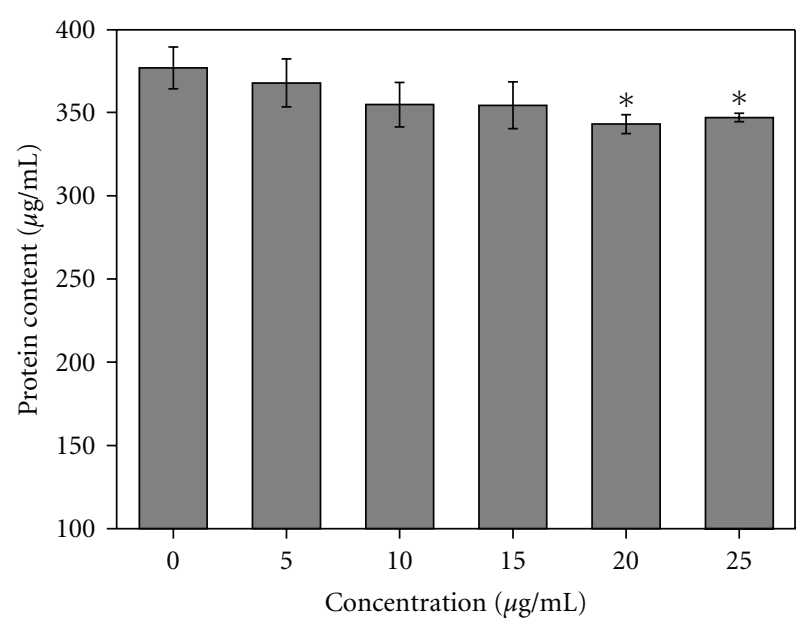

FIGURE 6: Total protein content of MG-63 cells cultured with different concentrations of n-HA for 5 days. Values are the mean $\pm \mathrm{SD}$ (six parallel samples for each concentration) ${ }^{*} P<$ 0.05 (compared to the $0 \mu \mathrm{g} / \mathrm{mL} \mathrm{n}-\mathrm{HA}$ group).

osteoblasts response to n-HA in other concentration ranges [8]. The protein-synthesizing activity, exhibited by the total intracellular protein content of the osteoblasts, could reflect the proliferation ability of the osteoblasts to some extent. Except for $20 \mu \mathrm{g} / \mathrm{mL}$ and $25 \mu \mathrm{g} / \mathrm{mL}$ groups, other experiment groups were not found obvious difference with the control group in the total protein content of osteoblasts. The biological effects of n-HA particles were concentration dependent; higher concentration was associated with adverse effects. Probably, the concentration of 5, 10,15 $\mu \mathrm{g} / \mathrm{mL}$ was relatively low without causing change of the total protein content of osteoblasts. The results showed that the biological effects of the cell viability and actin cytoskeleton on $\mathrm{n}$ HA show a descending trend with the increase of the nHA concentration. In addition, our study further revealed that the apoptosis rate of MG-63 cells were $1.85 \pm 0.06 \%$, $1.99 \pm 0.11 \%$, and $2.29 \pm 0.09 \%$, when the concentration

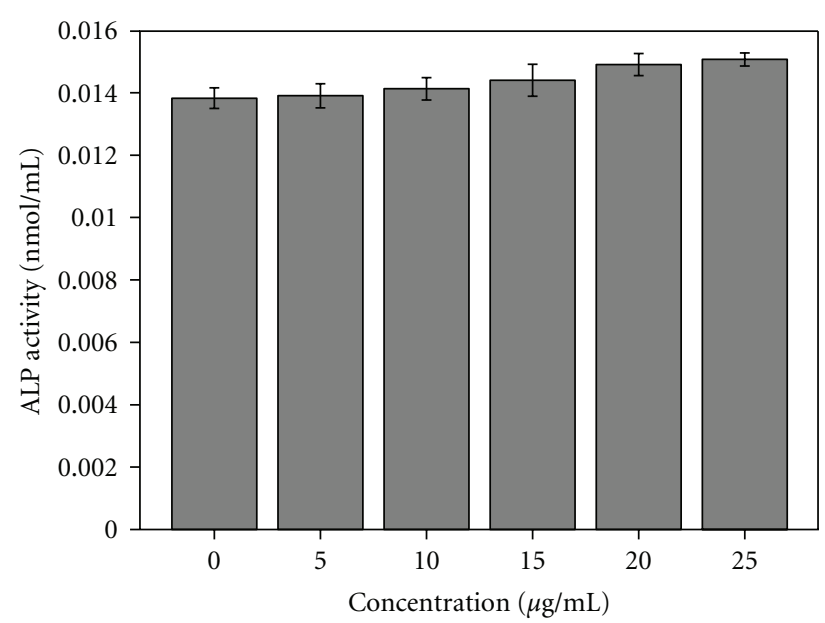

FIGURE 7: ALP activity of MG-63 cells cultured with different concentrations of $n-H A$ for 5 days. Values are the mean \pm SD (six parallel samples for each concentration).

of n-HA were 5,15 , and $25 \mu \mathrm{g} / \mathrm{mL}$, respectively. The results showed that the cell apoptosis rate showed a rising trend with the increase of the n-HA concentration.

Besides the viability of the cells in the coculture system of cells and n-HA particles, the differentiation is another important parameter to estimate the biological effects on different n-HA concentration. BCA assay and ALP activity assay were used to evaluate the differentiation of the MG63 cells in this study, and ALP activity was routinely used as an early marker of osteoblast differentiation in vitro. Our results confirmed that normal osteoblastic differentiation occurred on each group, and no significant statistical change was found between the control and experiment groups after 5 days of culture, which can be ascribed to the fact that the time point chosen in this study was not optimal for mineralization of MG-63 cells.

According to the above results, the obvious biological effects of the MG-63 cells on n-HA existed at the low concentration range from 5 to $25 \mu \mathrm{g} / \mathrm{mL}$, and the low concentration of n-HA showed slight toxicity to MG-63 cells. Firstly, the n-HA particles used in this study had been reported that it could penetrate the cell membrane into the cytoplasm in a nonreceptor-mediated fashion after 5 days [16] and smaller n-HA particles could enter into cells more easily and stimulate cells [17]. Additionally, the rod-like particles always induced the larger production of inflammatory cytokines than the spherical-like $[6,18]$. The n-HA might be interacted with the cell surface and had the potential to enter the cells, leading to the reduction of the proliferation and total protein content of the MG-63 cells.

Moreover, the n-HA nanoparticles could undergo phagocytosis by cells of the osteogenic lineage, with potential adverse effects on cellular viability, proliferation, and function. The biological effects of $\mathrm{n}$-HA on cells might be dependent not only on the composition, size, and shape but also on the concentration of nano particle [19]. Nano particles with the same size in high concentration appeared to stimulate proinflammatory factor release more than in low 
concentration. The released factors inhibited bone formation and stimulated osteoclast-mediated bone resorption. Therefore, the results demonstrated that the growth of the MG63 cells was inhibited by $n-H A$ in a concentration-dependent manner at the low concentration range from 5 to $25 \mu \mathrm{g} / \mathrm{mL}$.

\section{Conclusions}

In this study, the size-controlled n-HA particle was synthesized and its biological effects on osteoblast-like MG63 cells were evaluated at the relatively low concentration range. The results demonstrated that both cell proliferation and cell apoptosis were related to the concentration of n$\mathrm{HA}$. At the low concentration range from 5 to $25 \mu \mathrm{g} / \mathrm{mL}$, the n-HA inhibited the proliferation of MG-63 cells, and total intracellular protein content decreased with increase of the n-HA concentration. No significant change of ALP activity was observed after 5 days of culture.

Our results revealed that the obvious biological effects of the MG-63 cells on n-HA existed at the relatively low concentration range from 5 to $25 \mu \mathrm{g} / \mathrm{mL}$. The biological effects on viability and actin cytoskeleton of the MG-63 cells showed a descending trend with the increase of the n-HA concentration, and the cell apoptosis rate showed a rising trend with the increase of the n-HA concentration. It could be suggested that the growth of MG-63 cells was inhibited by $\mathrm{n}$-HA in a concentration-dependent manner at the relatively low concentration range. However, in the low concentration range, whether n-HA particles gathered around implant lead to local inflammatory reaction or not needs to be further researched.

\section{Acknowledgments}

This paper was supported by State Key Development Program for Basic Research of China (Grant 2007CB936103), the Fundamental Research Funds for the Central Universities, and Peking University's 985 Grant.

\section{References}

[1] T. B. Redd and P. K. Shivapuja, "Debonding ceramic brackets: effects on enamel," Journal of Clinical Orthodontics, vol. 25, no. 8, pp. 475-481, 1991.

[2] J. C. Hornez, F. Chai, F. Monchau, N. Blanchemain, M. Descamps, and H. F. Hildebrand, "Biological and physicochemical assessment of hydroxyapatite (HA) with different porosity," Biomolecular Engineering, vol. 24, no. 5, pp. 505509, 2007.

[3] W. Suchanek and M. Yoshimura, "Processing and properties of hydroxyapatite-based biomaterials for use as hard tissue replacement implants," Journal of Materials Research, vol. 13, no. 1, pp. 94-117, 1998.

[4] S. F. Hulbert, J. C. Bokros, L. L. Hench, J. Wilson, and G. Heimke, "Ceramics in clinical applications, past, present and future," High Tech Ceramics A, pp. 189-213, 1987.

[5] H. Oonishi, "Orthopaedic applications of hydroxyapatite," Biomaterials, vol. 12, no. 2, pp. 171-178, 1991.

[6] A. Grandjean-Laquerriere, P. Laquerriere, D. Laurent-Maquin, M. Guenounou, and T. M. Phillips, "The effect of the physical characteristics of hydroxyapatite particles on human monocytes IL-18 production in vitro," Biomaterials, vol. 25, no. 28, pp. 5921-5927, 2004.

[7] P. Laquerriere, A. Grandjean-Laquerriere, E. Jallot, G. Balossier, P. Frayssinet, and M. Guenounou, "Importance of hydroxyapatite particles characteristics on cytokines production by human monocytes in vitro," Biomaterials, vol. 24, no. 16, pp. 2739-2747, 2003.

[8] Z. Xu, J. Sun, L. Changsheng, and W. Jie, "Effect of hydroxyapatite nanoparticles of different concentrations on rat osteoblast," Materials Science Forum, vol. 610-613, pp. 13641369, 2009.

[9] Q. Fu, N. Zhou, W. Huang, D. Wang, L. Zhang, and H. Li, "Effects of nano HAP on biological and structural properties of glass bone cement," Journal of Biomedical Materials Research Part A, vol. 74, no. 2, pp. 156-163, 2005.

[10] M. Motskin, D. M. Wright, K. Muller et al., "Hydroxyapatite nano and microparticles: correlation of particle properties with cytotoxicity and biostability," Biomaterials, vol. 30, no. 19, pp. 3307-3317, 2009.

[11] Z. S. Liu, S. L. Tang, and Z. L. Ai, "Effects of hydroxyapatite nanoparticles on proliferation and apoptosis of human hepatoma BEL-7402 cells," World Journal of Gastroenterology, vol. 9, no. 9, pp. 1968-1971, 2003.

[12] R. D. Bloebaum, L. Zou, K. N. Bachus, K. G. Shea, A. A. Hofmann, and H. K. Dunn, "Analysis of particles in acetabular components from patients with osteolysis," Clinical Orthopaedics and Related Research, no. 338, pp. 109-118, 1997.

[13] W. Jie and L. Yubao, "Tissue engineering scaffold material of nano-apatite crystals and polyamide composite," European Polymer Journal, vol. 40, no. 3, pp. 509-515, 2004.

[14] P. K. Smith, R. I. Krohn, and G. T. Hermanson, "Measurement of protein using bicinchoninic acid," Analytical Biochemistry, vol. 150, no. 1, pp. 76-85, 1985.

[15] L. Yubao, J. De Wijn, C. P. A.T. Klein, S. Van de Meer, and K. De Groot, "Preparation and characterization of nanograde osteoapatite-like rod crystals," Journal of Materials Science, vol. 5, no. 5, pp. 252-255, 1994.

[16] Y. Cai, Y. Liu, W. Yan et al., "Role of hydroxyapatite nanoparticle size in bone cell proliferation," Journal of Materials Chemistry, vol. 17, no. 36, pp. 3780-3787, 2007.

[17] Z. Shi, X. Huang, Y. Cai, R. Tang, and D. Yang, "Size effect of hydroxyapatite nanoparticles on proliferation and apoptosis of osteoblast-like cells," Acta Biomaterialia, vol. 5, no. 1, pp. 338345, 2009.

[18] P. Laquerriere, A. Grandjean-Laquerriere, E. Jallot, G. Balossier, P. Frayssinet, and M. Guenounou, "Importance of hydroxyapatite particles characteristics on cytokines production by human monocytes in vitro," Biomaterials, vol. 24, no. 16, pp. 2739-2747, 2003.

[19] S. B. Goodman, T. Ma, R. Chiu, R. Ramachandran, and R. Lane Smith, "Effects of orthopaedic wear particles on osteoprogenitor cells," Biomaterials, vol. 27, no. 36, pp. 6096$6101,2006$. 

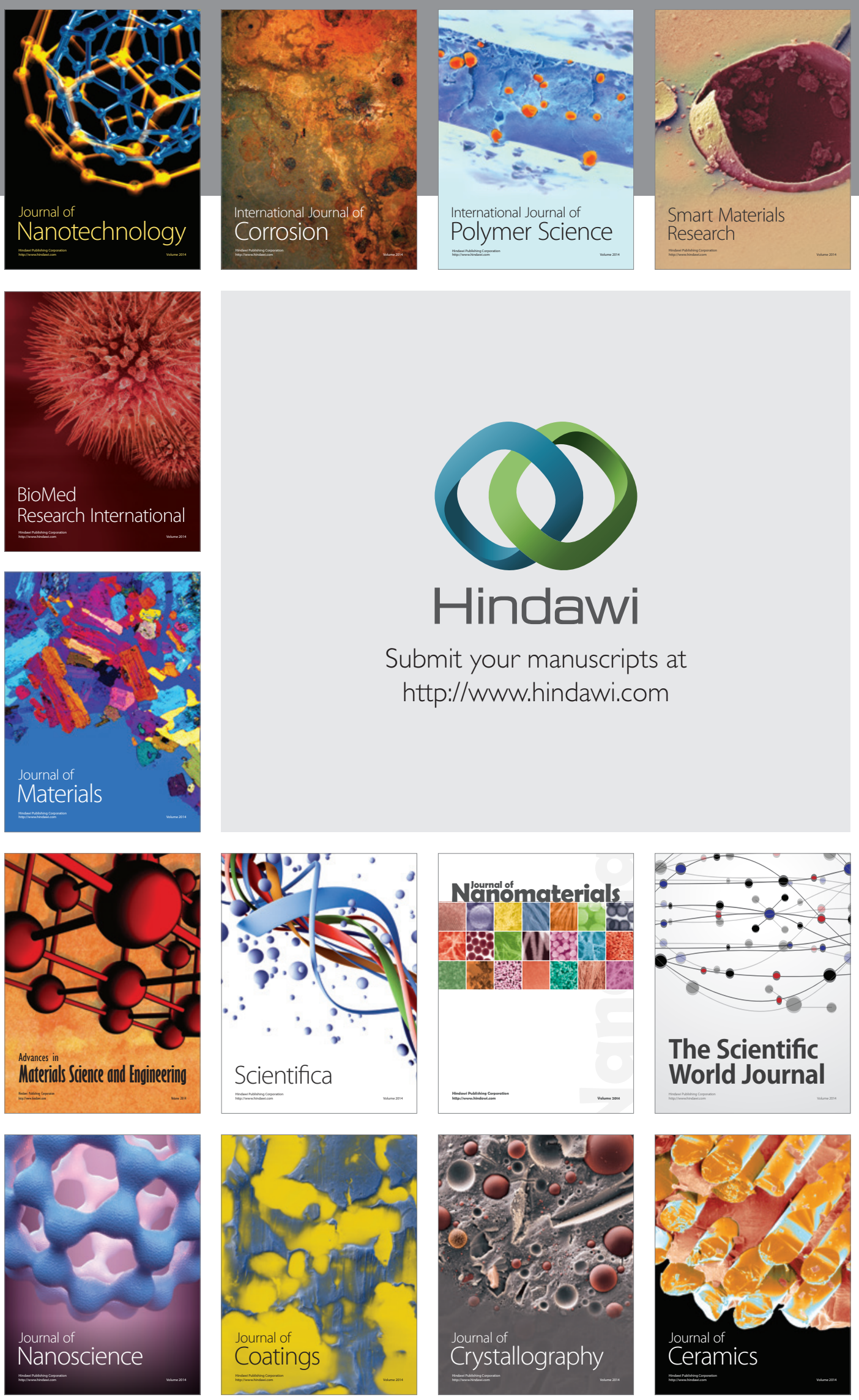

The Scientific World Journal

Submit your manuscripts at

http://www.hindawi.com

\section{World Journal}

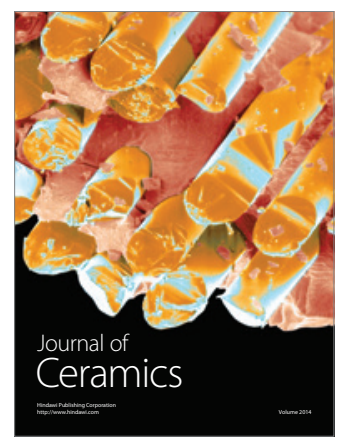

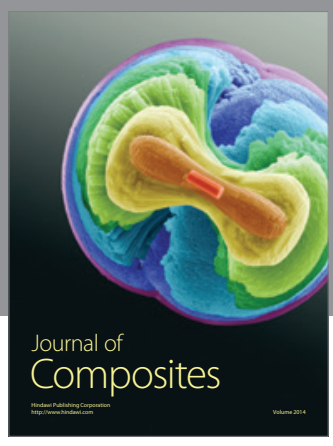
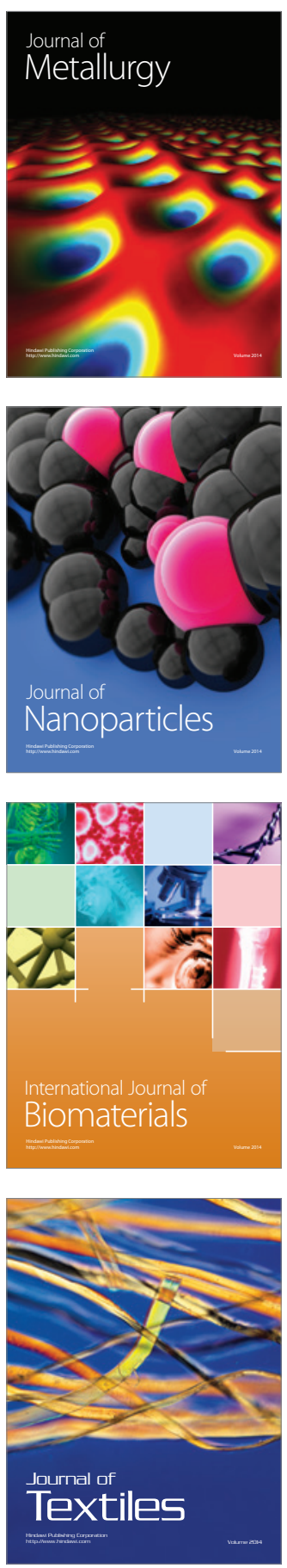